\title{
STUDI PERKUATAN BALOK BETON BERTULANG DENGAN STRAND TANPA PENEGANGAN DAN TULANGAN U
}

\author{
Ambar Susanto $^{1}$, Heri Kasyanto ${ }^{2}$, Susilahadi ${ }^{3}$. \\ 1,2,3 Staf pengajar Jurusan Teknik Sipil Politeknik Negeri Bandung \\ Jl. Gegerkalong Hilir Ds.Ciwaruga Kotak pos 1234 Bdg 40012 \\ Email: ${ }_{1}^{1}$ ambarsusanto@polban.ac.id, ${ }^{2}$ herikasyanto@polban.ac.id, ${ }^{3}$ susilahadi@polban.ac.id
}

\begin{abstract}
Increasing capacity of structures can be done by various methods, one of them is by reinforcing on bridge structure. Reinforcement by using strand has been used on building construction but on reinforced concrete beams because of the problems on it's execution. The focus of this research is how to install nonstressing strand as reinforcement material.

The basic of the research is full-scalled loading test on structure laboratory. There are 2 loading test samples : a sample without reinforcement $\left(B_{0}\right)$ and a sample with reinforcement $\left(B_{1}\right)$. The test specimen will be subjected to static monotonic loading until the collapse. The dimensions of the test specimen are $150 \mathrm{x}$ $300(\mathrm{~mm})$ and the length of the span is $3200 \mathrm{~mm}$.

The result of loading for the reinforced concrete beam and reinforcement beam, the yield force value was $22 \mathrm{kN}$ and $27 \mathrm{kN}$ respectively, while deflection value was $9.5 \mathrm{~mm}$ and $13 \mathrm{~mm}$ respectively.
\end{abstract}

Keywords: beam, reinforcement, strand without stressing, static load.

\begin{abstract}
ABSTRAK
Peningkatan kemampuan(kapasitas) infrastruktur khususnya jembatan dapat dilakukan dengan berbagai metode, salah satu untuk meningkatkan kemampuan tersebut dengan memperkuat jembatan.Perkuatan menggunakan strand sudah digunakan pada berbagai konstruksi bangunan tetapi untuk balok beton bertulang belum banyak dilakukan karena akan mengalami kesulitan dalam metode pelaksanaan. Sehingga dalam penelitian ini akan mencoba menggunakan metode pemasangan strand tanpa penegangan sebagai bahan perkuatan.

Penelitian dilakukan dengan cara pengujian eksperimental di laboratorium dan. Benda uji yang digunakan terdiri dari 2(dua) buah yaitu 1(satu) benda uji balok beton bertulang tanpa perkuatan(Bo) dan 1(satu) buah benda uji balok beton bertulang dengan perkuatan(B1). Benda uji akan dilakukan uji pembebanan statikmonotonik sampai mengalami keruntuhan. Dimensi benda uji 150 x 300 (mm) dan panjang bentang $3200 \mathrm{~mm}$.
\end{abstract}

Dari hasil pengujian terhadap balok beton tanpa perkuatan dan balok perkuatan didapatkan nilai gaya leleh berturut - turut sebesar $22 \mathrm{kN}$ dan $27 \mathrm{kN}$ serta lendutan berturut -turut sebesar $9.5 \mathrm{~mm}$ dan $13 \mathrm{~mm}$.

Kata kunci : balok, perkuatan, strand tanpa penegangan, beban statik

\section{PENDAHULUAN}

Penelitian perkuatan pada balok sudah banyak dilakukan salah satunya dengan menggunakan Fiber Reinforcement Polymer(FRP), baik untuk perkuatan lenturmaupun untuk perkuatan geser. FRP banyak digunakan karena keunggulannya, utamanya adalah dalam hal rasio antara kuat tekan tinggi terhadap berat serta ketahanannya yang baik terhadap korosi.

Renata,et al,2015[1], dalam penelitiannya memodifikasi perkuatan FRP dan profil I untuk meningkatkan kapasitas beban dan kekakuan balok beton.
Hamad,et al,2011[2] dalam penelitiannya tentang balok yang diperkuat dengan baja tulangan dan baja siku secara keseluruhan memperoleh peningkatan hasil yang berarti. Kapasitas penampang balok meningkat 3,2 kali dibandingkan dengan balok kontrol, yang berarti pula diperolehnya kuat geser dan ketahanan momen yang lebih tinggi.

Penelitian tentang perkuatan lentur balok tampang persegi dengan penambahan tulangan menggunakan perekat epoxy sudah dilakukan oleh Iswari dll ,2004[3]. Benda uji yang digunakan terdiri dari tiga 
buah tipe benda uji yaitu balok dengan tulangan perkuatan bagian tarik 1 tulangan (BP-B1), balok dengan tulangan perkuatan bagian tarik 2 tulangan dan tekan 1 tulangan (BP-A1B2), balok dengan tulangan perkuatan bagian tarik 3 tulangan dan tekan 2 tulangan (BP-A2B3) masing-masing berjumlah 2 buah.Terhadap balok normal yang dijadikan standar menunjukkan peningkatan kapasitas lentur sebesar 63,04 \%, 139,95 \% dan 124,14 \%. Kekakuan balok meningkat berturut turut sebesar $14,03 \%$, 41,04 \% dan 100,18 \% terhadap balok kontrol. Daktilitas balok turun berturut-turut sebesar 37,59 \%, 65,68\% dan 81,66 \% terhadap balok kontrol.

Perkuatan menggunakan strand sering kali digunakan pada perkuatan struktur dari bahan baja baik jembatan maupun gedung. Dari hasil perkuatan tersebut sudah dihasilkan perkuatan yang efektif buat material baja. Seperti penelitian yang dilakukan oleh Budiono dan Bakhtiar ,2012,[4] melakukan penelitian pengaruh letak beban terhadap gaya prategang tipe segitiga pada model jembatan rangka baja. Penelitian yang menggunakan kawat baja sudah pernah dilakukan tetapi bukan menggunakan strand melainkan menggunakan kawat baja jenis wire rope atau baja sling. Haryanto ,2011,[5] meninjau penelitian tentang efektifitas wire rope sebagai perkuatan pada daerah momen negatif balok beton bertulang tampang $\mathrm{T}$, dari hasil penelitin tersebut ternyata tegangan yang terjadi pada wire rope belum mencapai $50 \%$ dari tegangan ultimit.

\section{Bahan}

Bahan-bahan yang digunakan pada penelitian ini sebagai berikut:

a) Beton ready mix dengan mutu(fc') = $25 \mathrm{MPa}$.

b) Baja tulangan ulir dengan mutu(fy)= $400 \mathrm{MPa}$, diameter untuk baja ulir digunakan D-13 mm, sedangkan diameter baja polos digunakan $\varnothing 6$ $\mathrm{mm}$. c) Strand digunakan diameter 13 dengan mutu Grade 270.

Sedangkan benda uji yang digunakan merupakan balok beton bertulang dengan dimensi 150 x 300 x 3200 mm. Benda uji tersebut terdiri dari 1(satu) balok beton .

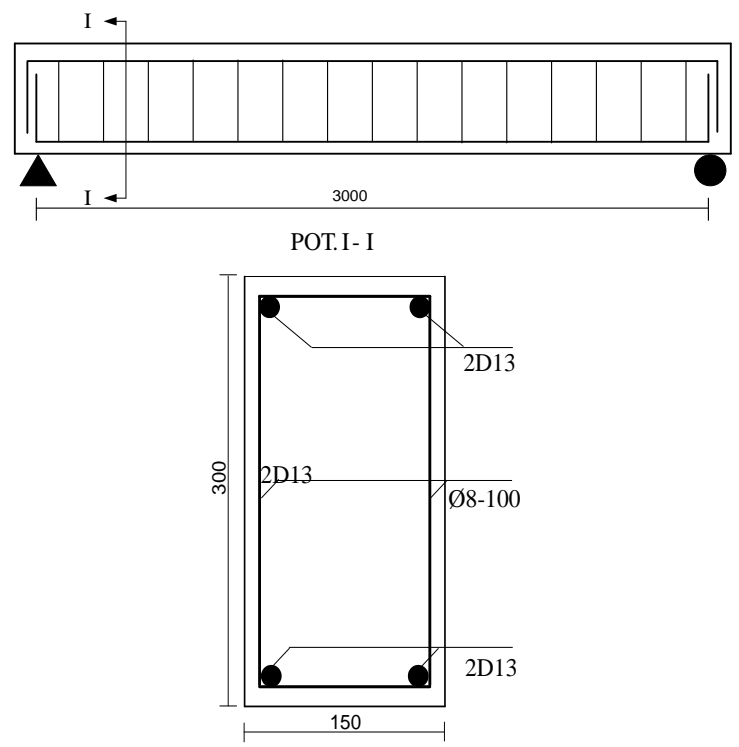

Gambar 1. Benda uji balok normal (Bo)

Sedangkan untuk benda uji dengan perkuatan dari strand seperti pada Gambar 2

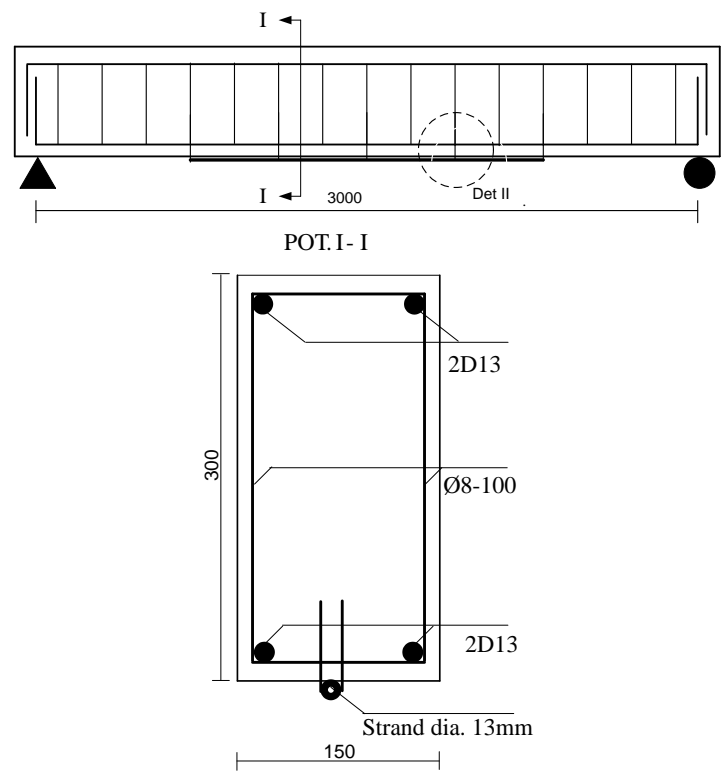

Gambar 2. Benda uji balok perkuatan (B1) 


\section{METODA PENELITIAN}

Secara garis besar penelitian ini dilakukan dengan pengujian eksperimental di laboratorium. Benda uji tersebut diuji dengan pembebanan static monotonik sampai mengalami keruntuhan dengan skema pengujian seperti pada Gambar 3.

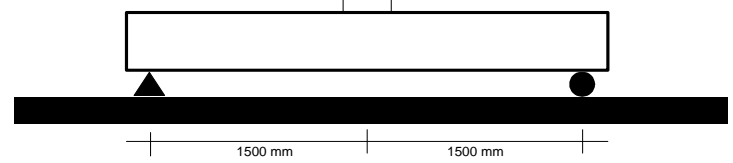

Gambar 3. Skema pengujian benda uji balok

Untuk mengukur parameter-parameter pengujian yang akan digunakan dalam menganalisa hasil pengujian,maka diperlukan alat-alat bantu berupa strain gage dan LVDT.Adapun penempatan ke 2 alat bantu tersebut seperti pada Gambar 4.

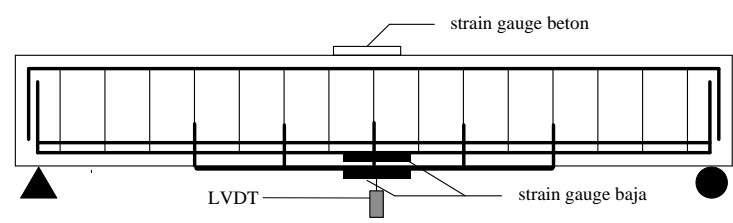

Gambar 4. Penempatan strain gage dan LVDT

\section{HASIL DAN PEMBAHASAN}

\section{Kurva beban - lendutan}

Dari hasil pengujian beban statikmonotonik untuk ke 2 jenis benda uji di atas (Bo dan B1) dapat dibuatkan suatu kurva hubungan antara beban dan lendutan seperti pada Gambar 3 dan 4. Pada saat pembebanan benda uji normal(Bo) berlangsung, retak awal terjadi apabila tegangan tarik beton sudah terlampaui, seiring dengan bertambahnya pembebanan, benda uji balok normal(Bo) mengalami leleh pada saat beban 22Kn dan lendutan yang terjadi sebesar $\mathbf{9 . 5} \mathrm{mm}$. Sedangkan untuk benda uji balok perkuatan (B1) retak awal terjadi apabila tegangan tarik dari beton sudah terlampaui,seiring dengan bertambahnya pembebanan, benda uji balok perkuatan mengalami leleh pada saat beban $27 \mathrm{kN}$ dengan lendutannya sebesar 13mm. Jadi dengan menambahkan perkuatan strand pada sisi bawah balok dan dipasangkan tulangan U serta direkatkan dengan epoxy dapat menaikkan beban leleh sebesar 22,727\%.

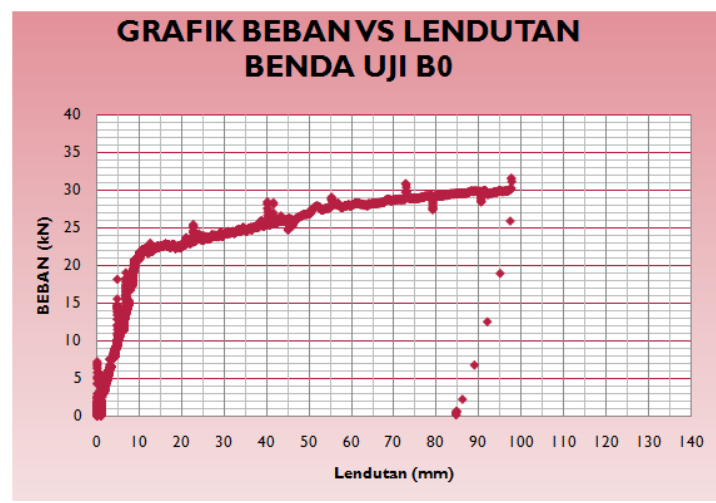

Gambar 3. Kurva beban - lendutan balok Bo

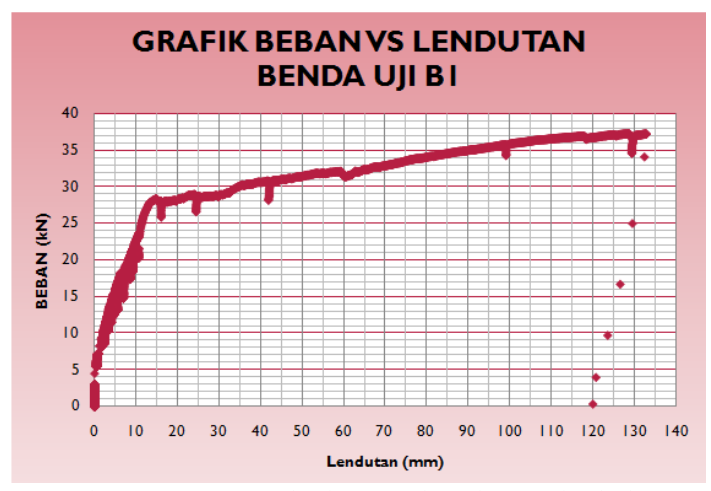

Gambar 4. Kurva beban - lendutan balok B1

\section{Polaretak}

Pada awal pembebanan, retak terjadi setelah tegangan tarik beton pada bagian bawah terlampuai, seiring bertambahnya pembebanan maka terjadi perambatan retak lentur pada balok tersebut hal ini ditandai dengan bentuk retaknya sebagain besar berupa retak vertikal disekitar posisi pembebanan, pola retak yang terjadi pada balok normal (Bo) seperti pada Gambar 5.

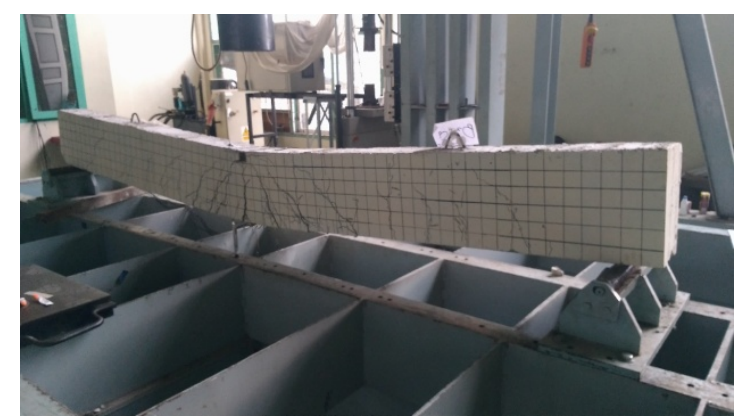

Gambar 5. Pola retak balok normal (Bo) 
Sedangkan untuk balok perkuatan (B1), retak terjadi setelah tegangan tarik beton pada bagian bawah terlampuai, seiring bertambahnya pembebanan maka terjadi perambatan retak lentur pada balok tersebut hal ini ditandai dengan bentuk retaknya sebagain besar berupa retak diagonal (flexure-shear) di sekitar posisi pembebanan, hal ini disebabkan dengan adanya pemasangan angkur (tulangan U) dalam jarak tertentu pada bagian bawah balok yang difungsikan sebagai tumpuan strand, sehingga tulangan U tersebut dapat dianalogikan (berfungsi) sebagai tulangan gesar. Pola retak yang terjadi pada balok perkuatan (B1) seperti pada Gambar6.

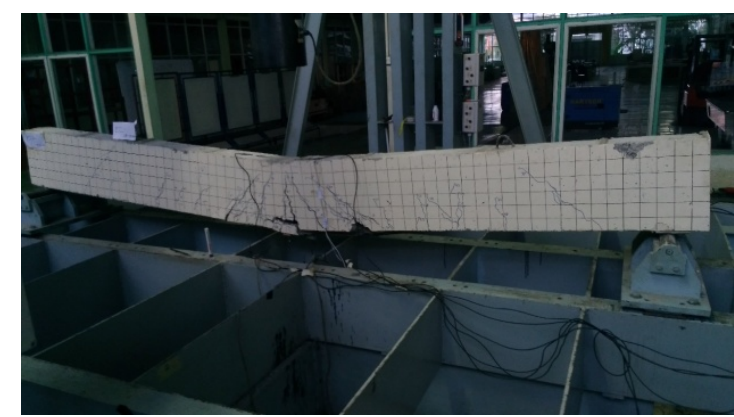

Gambar 6. Pola retak balok perkuatan (B1)

\section{KESIMPULAN}

Dari hasil pengujian terhadap ke 2 benda uji Bo dan B1 dihasilkan peningkatan beban pada saat leleh untuk benda uji balok B1 sebesar $27 \%$ terhadap benda uji Bo. Pola retak yang terjadi pada benda uji Bo merupakan retak lentur, sedangkanuntuk pola retak benda uji B1 merupakan retak - diagonal hal ini terjadi karena adanya pemasangan angkur(tulangan U) yang menjadi tumpuan dari strand, mekanisme ini seperti tulangan geser balok.

\section{DAFTAR PUSTAKA}

[1] Bilal Hamad,Adnan Masri,Hisham Basha, Oussama Baalbaki. 2011. "Behavior of T-Shaped Reinforced Concrete Beams Partially Confined by Structural Steel”. Construction Materials 25,1037 - 1043.
[2] Budiono, S.P., Bakhtiar, M.I. 2012. "Pengaruh Letak Beban Terhadap Gaya Prategang Tipe Segitiga Pada Model Jembatan Rangka Baja”. Vol 11 No 2, Jurnal Teknik Sipil, Yogyakata.

[3] Haryanto, Y. 2011. "Efektifitas Wire Rope Sebagai Perkuatan Pada Daerah Momen Negatif balok beton bertulang tampang T”. Volume 7 No 2, Dinamika Rekayasa.

[4] Iswari, Dian. A.Y, Triwiyono.A. 2014. Perkuatan Lentur Balok Tampang Persegi Dengan Penambahan Tulangan Menggunakan Perekat Epoxy" Thesis. Universitas Gadjah Mada, Yogyakarta.

[5] Renata Kotyniaand Szymon Cholostiakow. 2015. "Flexural Strengthening of Reinforced Beams Using CFRP T-Shape Profiles". Polymers,pp:2461-2477. 